\title{
SOCIÁLNĚ-PSYCHOLOGICKÉ ASPEKTY MOTIVACE A ROZVOJE PRACOVNÍKŮ
}

\section{Vojtěch Malátek}

\section{Klíčová slova:}

pracovník, motivace, pracovní spokojenost, lidský kapitál, rozvoj pracovníků, podniková kultura, podnik

\section{Key words:}

employee, motivation, job satisfaction, human capital, employee development, corporate culture, enterprise

\begin{abstract}
Abstrakt
Tento článek pojednává o motivaci a rozvoji pracovníků z pohledu sociálně-psychologických hledisek. Zdůrazněna je především důležitost těchto hledisek v rámci motivace a rozvoje pracovníků, tj. v personálních činnostech, jejichž adekvátní zvládnutí ze strany managementu podniků je jedním z jejich nejdůležitějších prostředků v tvrdém konkurenčním boji. Pouze „správně“ namotivovaní pracovníci s potřebnou úrovní znalostí, vědomostí, schopností a dovedností jsou tím nejcennějším zdrojem výkonu, které podnik má.
\end{abstract}

\begin{abstract}
This article deals with employee motivation and development from the social-psychological viewpoints. Primarily emphasized is the importance of these viewpoints in the scope of employee motivation and development, i.e. in personell activities which are, if they are appropriately handled by the enterprise management, one of the most important tools in the hard competition of these enterprises. Only properly motivated employees with required level of knowledge, learning, abilities and skills are the most precious performance resource which the enterprise has.
\end{abstract}

\section{Úvod}

„Organizace hospodářského i jiného typu jsou tvořeny více či méně početnými soubory lidí, mezi nimiž se nutně vytváří sociální interakce, a to v rovině formální (lidé sdružení z hlediska pracovních úkolů) a v rovině neformální (spontánní interakce mezi spolupracovníky téhož pracoviště a mezi zaměstnanci téže organizace). Fungování organizace je vyjádřeno řadou konstruktů (například pracovní spokojenost, podnikové klima, kariéra a další), které také nutně zahrnují sociálně psychologická hlediska, protože se v nich uplatňují zřetele k interpersonálním interakcím. “1 Podniky, resp. jejich vedení má v rukou velmi cenné nástroje, jak na tyto hlediska pozitivně působit a dosáhnout tak prostřednictvím svých pracovníků vytýčených cílů. Tyto nástroje se nazývají motivace a rozvoj pracovníků. Pracovníci by totiž měli mít v podniku vytvořené takové podmínky, aby byli schopni naplnit nejen svoje potřeby, ale také cíle podniku. Hlavními předpoklady $\mathrm{k}$ dosažení podnikových cílů jsou „správně“ namotivovaní pracovníci s potřebnou úrovní znalostí, vědomostí, schopností a dovedností. V dnešním moderním světě dochází neustále k změnám, např.

\footnotetext{
${ }^{1}$ NAKONEČNÝ, M. Sociální psychologie organizace. 2005, s. 89.
} 
technologickým, a proto je zapotřebí umět na tyto změny rychle reagovat. Podniky se musí umět přizpůsobit vnějším okolním podmínkám, proto jsou nejen pracovníci nuceni se rozvíjet.

Tento článek se ve dvou ucelených kapitolách věnuje motivaci a rozvoji pracovníků, tedy zmiňovaným „nástrojům“ vedení podniků $\mathrm{k}$ dosažení vytýčených cílů, a to $\mathrm{z}$ pohledu sociálně-psychologických hledisek těchto personálních činností. První kapitola nejprve pojednává obecně o pracovní motivaci, pracovní spokojenosti a vztazích mezi těmito „proměnnými“. Následně prezentuje vybrané teorie motivace pracovního jednání a poukazuje na jejich využitelnost v praxi. Druhá kapitola je věnována intelektuálnímu kapitálu pracovníků a jeho rozvoji.

\section{Motivace pracovníků}

\subsection{Motivace a pracovní spokojenost}

„Motivace je vnitřním procesem, který vyjadřuje touhu a vůli (ochotu) člověka vyvinout určité úsilí vedoucí k dosažení subjektivně významného cíle nebo výsledku.“² Pracovní motivace nám tedy sděluje to, co vede člověka $\mathrm{k}$ tomu, aby pracoval. Základním a prvotním motivem práce jedinců je zajišsění bytí svého či svých blízkých. Člověk tedy za svou pracovní činnost přednostně očekává adekvátní výši odměny za vykonanou práci, aby mohl obstarat své bytí. Z hlediska pracovní motivace je tento motiv jedním z motivů extrinsických, tj. $\mathrm{z}$ vnějšku působících. Důležitou roli nejen v pracovní motivaci, ale i obecně v jednání člověka, mají motivy intrinsické, tj. vnitřní, sobě vlastní. Takovým motivem pro pracovníka může být např́klad seberealizace či uspokojení z práce. V př́padě Maslowovy hierarchie potřeb můžeme $\mathrm{z}$ hlediska motivace pracovníků spatřovat intrinsické motivy na vyšších patrech této „pyramidy“, tzn. nejprve je dle této teorie pracovník motivován hodnotou odměny, úrovní pracovních podmínek, kvalitou ř́zení, mezilidskými vztahy apod., a teprve poté je ve svém výkonu motivován vnitřními motivy, jako např̀. postavením ve společnosti, úrovní autonomie jeho práce, seberealizací a uspokojením z práce ${ }^{3}$.

Jednou z charakteristik motivovaného pracovníka, který odvádí očekávaný výkon, je jeho pracovní spokojenost. Faktory, které ovlivňují pracovní spokojenost a pracovní výkon shrnul ve své publikaci Management. Eine verhaltenwissenschaftliche Einführung W. H. Staehle ${ }^{4}$ :

- „intristicky motivovaná práce koreluje pozitivně se spokojeností a negativně s absentismem a fluktuací;

- autonomie pracovníka koreluje pozitivně s pracovním výkonem i se spokojeností;

- demokratický styl řízení koreluje pozitivně se spokojeností, ale bud' pozitivně, nebo negativně s pracovním výkonem;

- organizační klima vyznačující se podporou, otevřenou komunikací a autonomií koreluje pozitivně se spokojeností a ve většině případů také s pracovním výkonem. ${ }^{\text {‘5 }}$

Z uvedeného vyplývá, že práce, která je pro jedince vnitřně motivující má pozitivní vztah k jeho pracovní spokojenosti, snižuje absentismus v práci a fluktuaci (odchod ze zaměstnání). Je otázkou, zda je pracovní spokojenost př́činou zlepšení pracovního výkonu, či naopak uspokojení z pracovního výkonu (z dobře odvedené práce) je důvodem pro vyšší pracovní

\footnotetext{
${ }^{2}$ TURECKIOVÁ, M. Řízení a rozvoj lidí ve firmách. 2004, s. 55.

${ }^{3}$ Blíže viz CEJTHAMR, V., DĚDINA, J. Management a organizační chování. 2005, s. 145.

${ }^{4}$ Blíže viz STAEHLE, W. H. Management. Eine verhaltenwissenschaftliche Einführung. 1985.

${ }^{5}$ NAKONEČNÝ, M. Sociální psychologie organizace. 2005, s. 115.
} 
spokojenost. V tomto se mnozí autoři zabývající se pracovní motivací neshodují. „Pracovní spokojenost není dosud $\mathrm{v}$ teorii chápána jednotně. Zobecnění poznatků k pracovní spokojenosti je problematické z důvodů vlivu mnoha proměnných. “6 Bývá však přijat názor, že vztah mezi mírou pracovní spokojenosti a kvalitou pracovního výkonu je oboustranný, neustále se ovlivňující. Pozitivní vlivy autonomie pracovníka na pracovní výkon a spokojenost jsou zřejmé a pochopitelné. Volnost v rozhodování pracovníka při výkonu práce má u dostatečně ambiciózních jedinců ${ }^{7}$ (ne všem pracovníkům může být vysoká míra volnosti poskytnuta) kladné př́nosy v nimi dosahovaném výkonu a pracovním uspokojení. Demokratický styl řízení pracovníků ve většině př́padů navozuje pocity spokojenosti na pracovišti a především s prací samotnou, nebot' pracovníci nekonají svou práci výhradně na základě pokynů a př́íkazů ze strany jejich vedoucích. Vlivy demokratického stylu rrízení na pracovní výkon spočívají v úrovni liberálnosti tohoto stylu řízení. Je-li prŕliš liberální, může docházet k situacím, že výkon pracovníků není vůbec, nebo jen v malé míře kontrolován, což může u některých pracovníků vést k poklesu produktivity. Vhodně ,„nastavené“ organizační klima neboli vyvážená firemní kultura, s níž jsou zaměstnanci nejen seznámeni, ale především ztotožněni, se kladně odráži jak v pracovním výkonu, tak v pracovní spokojenosti pracovníků. Je evidentní, že při sociálně-psychologickém působení na pracovníky v rámci řízení lidských zdrojů, je nutné nezapomínat především na ty aspekty, které mají kladné vlivy na pracovní spokojenost a výkonnost pracovníků. Další faktory ovlivňující pracovní spokojenost pracovníků zobrazuje následující schéma, které je založeno na modelu pracovní spokojenosti E. A. Lockeho ${ }^{8}$.

Schéma 1: Pracovní spokojenost

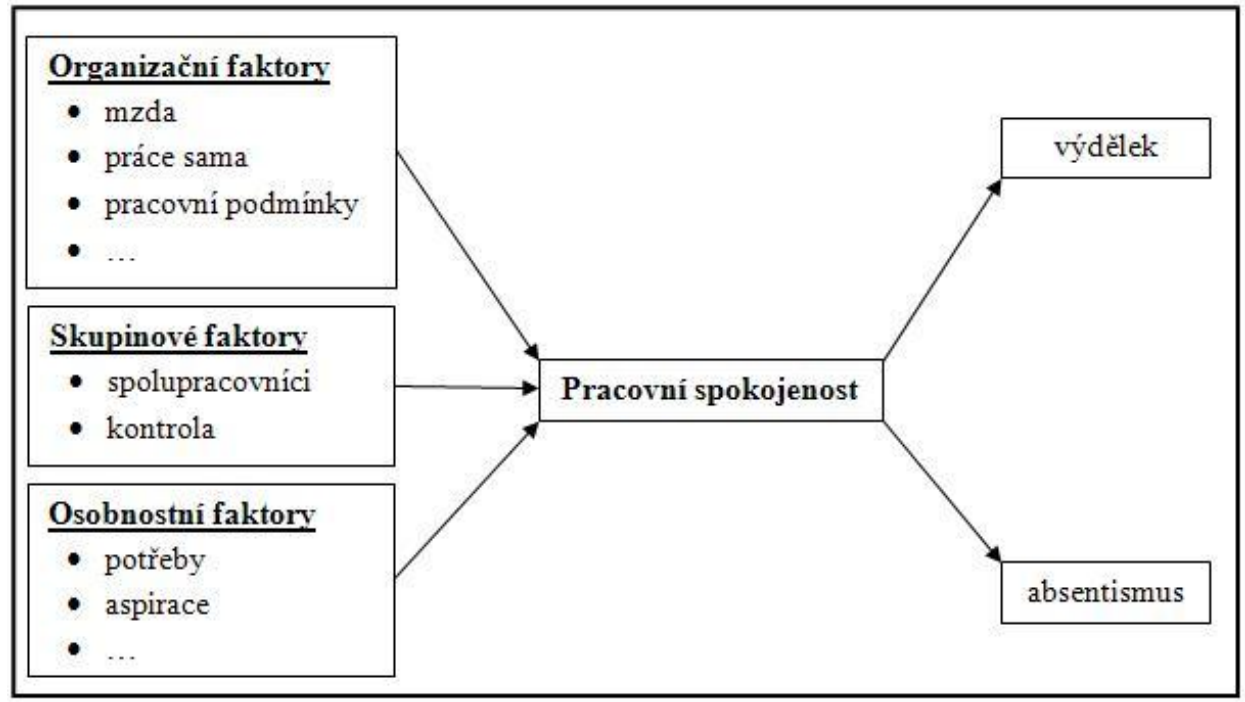

Zdroj: NAKONEČNÝ, M. Sociální psychologie organizace. 2005, s. 112.

Tento model shrnuje činitele, které mají vliv na pracovní spokojenost, do tří kategorií. Z hlediska organizačních faktorů lze zmínit výši a spravedlivost přidělované mzdy, která zaměstnanci př́sluší na základě jasných a transparentních pravidel. Dále jsou zde zahrnuty pracovní podmínky, kvalita pracovního prostředí a spokojenost s prací samotnou. Do skupinových faktorů se řadí styl řízení lidí (autokratický, demokratický), organizační hierarchie (vztahy nadřizenosti a podřizenosti), úroveň kontroly vykonávaných činností

\footnotetext{
${ }^{6}$ KOCIÁNOVÁ, R. Personální činnosti a metody personální práce. 2010, s. 35.

7 Ambicióznost pracovníků je z tohoto pohledu pouze jedním z kritérií pro umožnění větší autonomie pracovníkova rozhodování. Jako další kritéria lze uvést např. postavení v organizační hierarchii, typ vykonávané práce, množství podřízených pracovníků apod.

${ }^{8}$ Blíže viz LOCKE, E. A., LATHAM, G. P. Goal setting : a motivational technique that works! 1984.
} 
a kvalita mezilidských vztahů se spolupracovníky. Neméně významné faktory pracovní spokojenosti jsou též osobnostní činitelé, které odráží úspěšnost realizace vlastních potřeb, aspirací a ambicí pracovníků ve všech spektrech jejich pracovního života. Působí-li výše uvedené faktory na pracovníka pozitivním charakterem, poté, dle autora modelu, dochází ke zvyšování míry jeho pracovní spokojenosti. Úroveň pracovní spokojenosti má následně dopady na dvě oblasti - výdělek a absentismus. Pozitivní míra pracovní spokojenosti se odráží v poklesu absence pracovníků v práci a v poklesu jejich fluktuace. Pracovní spokojenost působí, jak bylo uvedeno výše, na pracovní výkon, jehož kvalitu by měl odrážet výdělek za odvedenou práci. Výdělek má pak zpětnovazební vliv na úroveň pracovní spokojenosti. Míru pracovní spokojenosti pak E. A. Locke definuje jako rozdíl mezi očekávanou a skutečnou pracovní situací vynásobený mírou významnosti takto posouzené situace (viz níže uvedený vzorec).

MPS - míra pracovní spokojenosti

Sps - skutečná pracovní situace

MPS $=($ Ops - Sps $) *$ MV

Ops - pracovníkem očekávaná pracovní situace (z hledisky výše uvedených faktorů)

MV - míra významnosti, kterou pracovník přikládá odchylce Sps od Ops

Je pochopitelné, že tento model je teoretickým konceptem, který nemůže zahrnout veškeré sociálně-psychologické aspekty, které působí na chování a jednání jedince v pracovním procesu, nicméně poukazuje na relevantní činitele, jež by neměly být při motivaci pracovníků opomíjeny. $\mathrm{V}$ další části budou popsány vybrané teoretické př́istupy $\mathrm{k}$ motivaci pracovníků s ohledem na jejich praktické využití v pracovním procesu.

\subsection{Teorie pracovní motivace a možnosti jejich aplikace v praxi}

Cílem řízení lidských zdrojů jako procesu je realizovat takové činnosti, tj. měnit sociální klima v podniku a pozitivně působit na psychiku jednotlivců a skupin na pracovišti, které pomohou co nejvíce pracovníkům daného podniku přiblížit prrístup $\mathrm{k}$ jejich práci nad úroveň „nutného zla“" (viz následující graf).

\section{Graf 1: Postoj pracovníkủ k práci}

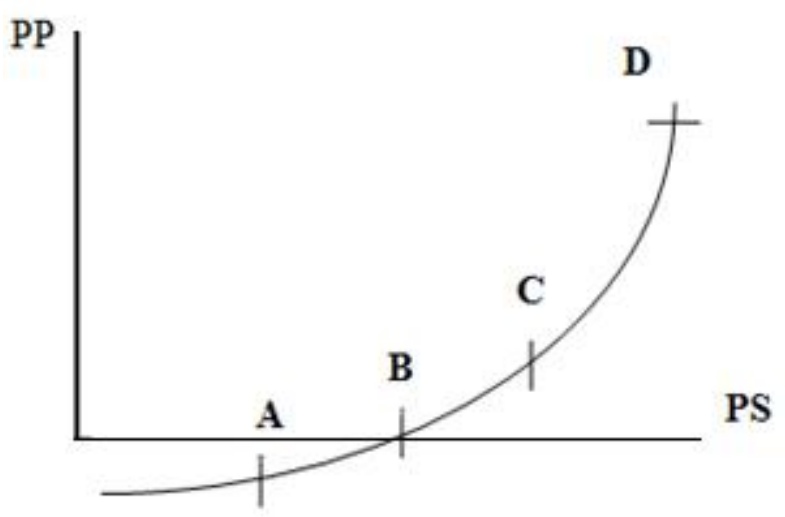

Zdroj: Vlastní zpracování
PP - postoj pracovníkủ k práci

PS - pracovní spokojenost (s pracovními podmínkami a praci obecně)

A - situace „odmitání práce" (PS nabývá od počátku až po bod $\mathrm{B}$ zápomých hodnot)

B - situace ,práce jako nutné zlo" (PS je rovna 0 , tj. pracovník již není nespokojen, ale jeho PS je nedostatečná, nemotivujici) C - situace „uspokojivá práce" (PS je kladná, motivujicí)

D - situace "práce jako druh zábavy" (PS je max., práce jedince zcela uspokojuje)

\subsubsection{Vroomova teorie pracovní motivace}

Obecnou tezí teorie pracovní motivace V. H. Vrooma, který je považován za jednoho z nejvýznamnějších představitelů psychologie práce 20. století, je skutečnost, že „síla 
tendence k určité činnosti závisí na síle očekávání, že důsledkem této činnosti bude získání určité hodnoty (peníze, uznání, prestiž atd.), přičemž platí, že pracovník k dosažení této hodnoty vynakládá tím větší úsilí, čím je daná hodnota pro něj atraktivnější. “9 Tato teorie je tak zařazena do kategorie teorií očekávání. Soustředí se v obecné rovině na kritéria toho, co by mělo vést pracovníka $\mathrm{k}$ žádanému výkonu, ale již konkrétně nesděluje, $\mathrm{v}$ jakých oblastech je vhodné na pracovníka působit. Pouze okrajově se zmiňuje o pracovníkem očekávané hodnotě platu, povýšení, uznání či seberealizace. Vroomova teorie se tak spíše zabývá „filozofií“ pracovní motivace, než samotnými motivy, které by měly být při sociálněpsychologickém působení na pracovníky ovlivňovány, přestože sám $\mathrm{V}$. H. Vroom v jiných souvislostech vymezil důvody lidské práce (peníze, sociální interakce, sociální status). Tato teorie naráží mimo jiné na skutečnost, že snadné úkoly, kde je vysoký předpoklad splnění cíle, budou silně motivační pro pracovníka, nebot' jak praxe, tak kritici této teorie poukázali na fakt, že snadný úkol je stejně neatraktivní jako př́liš náročný, tzn. nemotivující ke zvyšování výkonnosti. Praktické využití Vroomovi teorie v nezměněné podobě je považováno za sporné.

\subsubsection{Herzbergova dvoufaktorová teorie pracovní spokojenosti}

Dvoufaktorová teorie motivace F. Herzberga je založena na předpokladu, že jedince k plnění žádoucího pracovního výkonu stimuluje jeho pracovní spokojenost, která je v pracovním procesu utvářena dvěma skupinami faktorů - motivátory (satisfaktory) a frustrátory (hygienické faktory či dissatisfaktory), přičemž aspekty obou faktorů mohou na pracovníka působit bud' pozitivním či negativním účinkem. Pozitivní účinek motivátorů (dobře odvedená práce, uznání, vyhlídky na kariérní postup, seberealizace) se odráží v pracovní spokojenosti a adekvátním výkonu. Naopak pracovní nespokojenost a nižší než očekávaný výkon je důsledkem negativních účinků motivátorů (špatně odvedená práce, neprojevené uznání, nemožnost kariérního postupu, nemožnost seberealizace). Pozitivní účinek frustrátorů se projevuje tak, že pracovníci nejsou nespokojeni. Jako př́iklady tohoto účinku na pracovní spokojenost lze uvést dobrý plat, jistotu pracovního místa, dobré pracovní podmínky, prestiž. Negativní účinek frustrátorů způsobuje pracovní nespokojenost (špatný plat, nejistota pracovního místa, špatné pracovní podmínky, nízký status místa). „Naplňování potřeb druhé skupiny nemotivuje jedince $\mathrm{k}$ vyšší míře uspokojení z práce ani $\mathrm{k}$ vyššímu pracovnímu výkonu. Všechno, co můžeme očekávat od uspokojení této druhé skupiny potřeb, je prevence nespokojenosti a špatného pracovního výkonu. “10 Přestože má Herzbergova teorie řadu kritiků, kteří především poukazují na skutečnost, že přímá závislost pracovního výkonu na pracovní spokojenosti nebyla empiricky prokázána a vztah těchto dvou proměnných může být obousměrný (viz také kapitola 1.1), tak lze konstatovat, že pro využití této teorie v praxi motivace pracovníků je vhodné se zaměřit na pozitivní účinky motivátorů a s ohledem na typ pracovního místa se pokusit, aby alespoň některé frustrátory působily standardně pozitivním účinkem.

\subsubsection{Teorie spravedlnosti}

Teorie spravedlnosti (teorie rovnováhy vydání a zisku), jejímž hlavním představitelem je J. S. Adams, je založena na principu porovnání zisků zaměstnance za odvedené úsilí vůči ziskům druhého zaměstnance (skupiny zaměstnanců) za jím odvedené úsilí. Jediným motivem pracovního výkonu je tedy dle této teorie pouze odměna, resp. veškeré její složky (finanční; hmotné; nehmotné). Nabude-li pracovník dojmu, že poměr jeho zisku (odměny) k vynaloženému úsilí není roven tomuto poměru porovnávaného pracovníka, pak je vnitřně

\footnotetext{
${ }^{9}$ NAKONEČNÝ, M. Motivace pracovního jednání a její řízení. 1992, s. 72 - 73.

${ }^{10}$ ARMSTRONG, M. Řízení lidských zdrojů. Nejnovější trendy a postupy. 2007, s. 227.
} 
motivován měnit svůj pracovní výkon. Je-li tento poměr u porovnávaného pracovníka vyšší, pak je pracovník tzv. pod-placen (podhodnocen) a sníží svůj pracovní výkon. V opačném př́padě je pře-placen (nadhodnocen) a svůj výkon zvyšuje. Přestože teorie řízení lidských zdrojů ukazují, že s rostoucí odměnou ne vždy roste pracovní výkon, je možné z teorie spravedlnosti abstrahovat pro účely motivace pracovníků v praxi důležitý závěr, a to že výše a skladba odměny musí být pracovníkům poskytována na základě jasných pravidel, personálních procesů (analýzy pracovních míst, hodnocení práce, hodnocení pracovníků ad.) a hlavně spravedlivým způsobem pro všechny zaměstnance.

\subsubsection{Teorie $\mathrm{X}$ a $\mathrm{Y}$}

Tato teorie pracovní motivace, kterou vytvořil D. McGregor, vychází z předpokladu, že existují dva typy pracovníků, v nichž je vhodným motivačním „stylem“ ze strany nadřízeného vyvoláno očekávané pracovní jednání. Teorie X říká, že průměrný člověk nerad pracuje, je přirozeně líný, nespolehlivý a je-li to možné, tak se práci vyhne. Z těchto důvodů musí být většina pracovníků motivována finanční odměnou a hrozbou sankcionování. „Teorie X představuje realizaci centrálního principu vedení stanovením návodů, př́kazů a kontrolou řízených pracovníků, která je spojena s realizací forem autoritativního vedení. “11 Naopak teorie Y vychází ze skutečnosti, že lidé přirozeně touží po svém rozvoji, tvořivé práci a nezávislosti v rozhodování. Podle posouzení pracovníků pak konkrétní manažer uplatňuje takovou motivační politiku v rozmezí hraničních „bodů“ $\mathrm{X}$ a Y. „Manažeři, kteří se spoléhají jen na motivační funkci peněz, s velkou pravděpodobností vytvoří ve skupině prostředí, kde skutečně peníze budou nejdůležitější a vztahy na pracovišti budou zobrazovat to, co je obsaženo $\mathrm{v}$ teorii $\mathrm{X}$. Naopak manažeři zaměření na lidské vztahy mohou svým působením vytváŕet prostředí, kde se stanou mezilidské vztahy důležitými i pro ty členy pracovní skupiny, pro které původně hrály roli v jejich motivaci jen materiální odměny.“" ${ }^{\text {“12 }}$

Z hlediska historického vývoje teorií motivace či teorií pracovního jednání (především ve 20 . století) by bylo možné zmínit ještě mnoho teorií (např. Porterova a Lawlerova teorie očekávání, Schachterova afiliační teorie, Whiteova teorie kompetence, humanistické teorie pracovní motivace, teorie cukru a biče atd.) a desítky jejich modifikací. S většími problémy bychom ovšem nacházeli možnosti a konkrétní př́klady jejich uplatnitelnosti $\mathrm{v}$ nemodifikované podobě $\mathrm{v} \operatorname{praxi}^{13}$. Je možné konstatovat, že $\mathrm{v}$ reálném podnikovém managementu dochází v procesu motivování pracovníků obvykle ke kombinaci více metod a modelů sociálně-psychologického působení na pracovníky tak, aby bylo dosaženo kýženého výsledku, tj. plnění vytýčených cílů v neúprosném boji s konkurencí.

\section{Pracovník a jeho rozvoj}

\subsection{Pracovník jako součást intelektuálního kapitálu}

V současnosti podniky kladou stále větší důraz na rozvoj svého lidského kapitálu a svých pracovníků. Pojmem lidský kapitál se v současné době zabývá mnoho autorů. V tomto článku lze za východiskovou definici považovat definici J. Vetešky, který lidský kapitál vysvětluje jako vědění a dovednosti, které podporují osobní, sociální a ekonomický blahobyt a kvalitu

\footnotetext{
${ }^{11}$ DVOŘÁKOVÁ, Z. a kol. Management lidských zdrojů. 2007, s. 175.

12 PAUKNEROVÁ, D. a kol. Psychologie pro ekonomy a manažery. 2012, s. 178.

${ }^{13}$ Blíže viz DVOŘÁKOVÁ, Z. a kol. Management lidských zdrojů. 2007, s. 176 - 183.
} 
života. Pracovníci v podniku, jsou tedy nositeli znalostí a dovedností a stávají se nezbytnou součástí intelektuálního kapitálu. Na obrázku č. 1 je zobrazena interakce mezi lidským, strukturálním a sociálním kapitálem.

\section{Obr. č. 1 - Intelektuální kapitál}

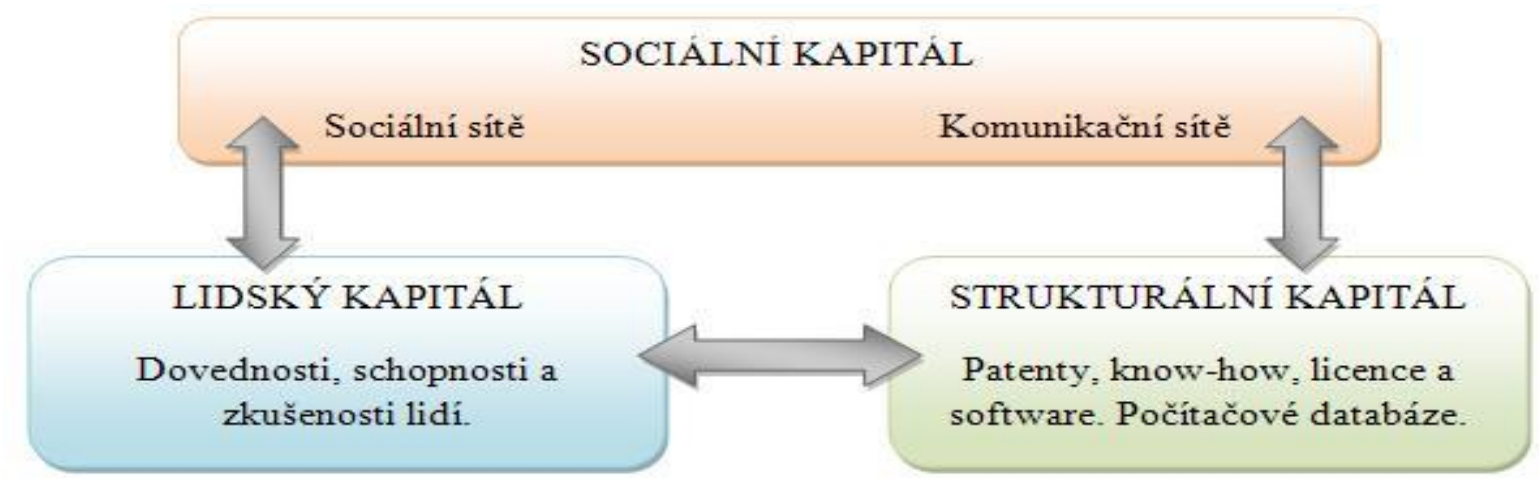

Zdroj: Vlastní zpracování dle http://managementmania.com/intelektualni-kapital

Intelektuální kapitál vymezil v roce 1988 Švéd Karl-Erik Sveiby, který tento kapitál člení do tř́ forem:

a) „Lidský kapitál - dovednosti, schopnosti a zkušenosti lidí. Jde o potenciál skrytý v hlavách lidí, který nemusí být nijak zachycen, ale pro podnik je navýsost žádoucí umět tento potenciál sdílet a využívat.

b) Strukturální kapitál - účetně evidované patenty, vzory, licence a software. Tento kapitál zahrnuje znalosti uložené v počítačových databázích, dále existující knowhow. Jedná se o akumulované zkušenosti podniku, které jsou nějak uchované a užívané při běžném provozu a rozvoji podniku.

c) Sociální kapitál - sociální vazby se zákazníky, jejich loajalita apod.“ ${ }^{14}$

„Sociální kapitál je tvořen znalostmi odvozenými ze sítě vztahů uvnitř podniku i mimo něj. Zahrnuje sítě mezilidských vztahů (sociální sítě) a komunikační systémy (komunikační sítě) umožňující výměnu a sdílení znalostí a společné řešení problémů př̀i každodenním fungování podniku. Pojem sociální kapitál definoval R. Putnam jako rysy společenského života - sítě vztahů, normy, očekávání a závazky - které umožňují účastníkům společně efektivněji pracovat při sledování sdílených cílů. “"15 Tento kapitál je tedy nezbytnou součástí podniku.

„Lidský, strukturální a sociální kapitál jsou ve vzájemné interakci. Mezi lidským a sociálním kapitálem vzniká provázanost především na základě komunikačních vztahů. Vytváŕí se kooperativní vztahy mezi jedinci, pracovním týmem, které v důsledku ovlivňují vztahy firmy k potřebám zákazníků. Sociální a strukturální kapitál vytváří takovou podnikovou kulturu, organizační chování, IS/IT technologie, které v konečném důsledku povedou k uspokojení zákazníka.“16

Je patrné, že lidský, strukturální a sociální kapitál je nezbytnou součástí každého podniku. Podniky si tuto skutečnost uvědomují a vyvijí aktivity, které slouží k rozvoji těchto kapitálů.

\footnotetext{
${ }^{14}$ Intelektuální kapitál [online], [cit. 2011-06-23].

${ }^{15}$ ARMSTRONG, M. Ŕízení lidských zdrojů. Nejnovější trendy a postupy. 2007, s. 51.

${ }^{16}$ PITUCHOVÁ, I. Lidský kapitál a jeho význam. 2011.
} 


\subsection{Rozvoj pracovníků}

Podniky si již začínají uvědomovat skutečnost, že jejich pracovníci jsou zdrojem budoucí hodnoty, a proto je důležité rozvíjet jejich znalosti a dovednosti. Rozvíjet lidský kapitál lze třemi způsoby. Podniky se věnují problematice zlepšování zdravotního stavu svých pracovníků, organizují kondiční pobyty, welness pobyty apod. „Mezi výhody, které podpora zdraví zaměstnanců podniku přináší, patří zlepšení pracovní pohody a zdraví zaměstnanců a z toho vyplývající pokles krátkodobé a především dlouhodobé pracovní neschopnosti a zvýšení produktivity práce, dále snížení počtu chorob souvisejících s prací a pracovních úrazů a veposlední řadě také zlepšení pověsti a atraktivity podniku u pracujících i konkurence. Podniky se zaměřují na zdravou výživu, prevenci a kontrolu nadváhy a obezity, odvykání kouření, zvyšování pohybové aktivity, prevenci traumatického poškození z práce a rehabilitaci, zvládání a léčbu nadměrného stresu, prevenci akutních respiračních onemocnění, prevenci kardiovaskulárních onemocnění, prevenci nádorových onemocnění." "17 Dalším způsobem rozvoje pracovníků je získávání zkušeností na zahraničních stážích. Pokud podniky chtějí svým pracovníkủm umožnit zahraniční stáž, musí mít dostatečné finanční prostředky k uskutečnění těchto aktivit. Tyto prostředky může získat pomocí grantů. Zahraniční stáže jsou také často dotovány z fondů EU. Třetím způsobem rozvoje pracovníků je vzdělávání.

„Vzdělávání je proces cílevědomého a systematického zprostředkování, osvojování a upevňování schopností, znalostí, dovedností. Nahrazuje, doplňuje, rozšiřuje, inovuje, mění a jinak obohacuje počáteční vzdělání dospělých osob, které záměrně a intencionálně rozvíjejí své znalosti a dovednosti potřebné pro plnohodnotnou práci a plnění životních a společenských rolí.“"18 „Podnikové vzdělávání je hlavním nástrojem rozvoje zaměstnanců ve smyslu zdokonalování, rozšiřování, prohlubování anebo změny struktury a obsahu jejich profesní způsobilosti a tím vlastně také příspěvkem $\mathrm{k}$ vyšší výkonnosti pracovníků i firmy jako celku.“19 „Podnikové vzdělávání nelze chápat pouze jako předávání poznatků, ale především jako permanentní zkvalitňování lidských zdrojů. Není reálné přímo řídit znalosti „V hlavách“ pracovníků, lze však řídit prostředí, v němž lidé pracují. Podnikové vzdělávání dotváŕí osobnost pracovníků a jejich hodnotovou orientaci a je nezbytným doplňkem kvalifikačního vzdělávání.“20

Dle J. Vodáka a A. Kucharčíkové podnikové vzdělávání pracovníků utváŕí podnikovou kulturu, která se stává jedním z významných faktorů konkurenceschopnosti. ,Je tomu tak proto, že technologie je možné získat snadno, avšak vhodná podniková kultura, která se projevuje očekávaným chováním zaměstnanců k interním a externím zákazníkům se tak snadno napodobit nedá.“21 „Podnikovou kulturu lze chápat jako soubor základních předpokladů, hodnot, postojů a norem chováni $i^{22}$, které jsou sdíleny v rámci podniku a které se projevují v myšlení, cítění a chování členů podniku. “23

\footnotetext{
${ }^{17}$ LIPŠOVÁ, V., ŠAMÁNEK, J., VAVŘINOVÁ, J. Kriteria kvality podpory zdraví na pracovišti. 2005, s. 2 a 8.

${ }^{18}$ PALÁN, Z. Lidské zdroje - Výkladový slovník. 2002, s. 237.

${ }^{19}$ TURECKIOVÁ, M. Řizení a rozvoj lidí ve firmách. 2004. s. 89.

20 ŠERÁK, M. Zájmové vzdělávaní dospělých. 2009. s. 23.

${ }^{21}$ VODÁK, J., KUCHARČÍKOVÁ, A. Efektivní vzdělávání zaměstnanců. 2011, s. 155.

${ }^{22}$ Blíže viz Mika, J. Etyka w edukacji dorosłych-andragogice. 2011, s. 13-16.

${ }^{23}$ LUKÁŠOVÁ, R., NOVÝ, I. a kol. Organizační kultura. 2004, s. 22.
} 
„Vzdělávání má být zaměřeno především na získávání takových znalostí a vědomostí, které povede k utváření strategie a stanovení zásad podnikové kultury.“24 Podniková kultura pozitivně ovlivňuje pracovní výkonnost pracovníků, vztahy uvnitř podniku a splynutí pracovníků s podnikovou kulturou. Vzdělávání pracovníků cíleně působí na lidský kapitál, čímž se formuje chování lidí, tedy v konečném důsledku se podílí na tvorbě hodnoty, postoje a normy chování pracovníků.

V současnosti lze nalézt nespočet názorů na členění podnikové kultury. Pro potřeby tohoto článku budeme považovat za stěžejní čtyři podnikové kultury, které ve své knize Rozvoj a vzdělávání pracovníků popisuje F. Hroník.

1. Kultura ostrých hochů - Tato podniková kultura nastavuje tzv. vysokou lat'ku. Pouze špičkoví jedinci dostanou možnost se v podniku rozvíjet a vzdělávat. Kulturu ostrých hochů využívají především podniky, které pracují v konkurenčním prostředí.

2. Kultura přátelských experimentů - Zde je ceněná týmová spolupráce. Pracovníci mají bezbariérový přístup $\mathrm{k}$ rozvíjení a vzdělávání. Je zde uplatňován př́stup týmového učení.

3. Kultura jízdy na jistotu - Veškeré činnosti jsou předem jasně a zřetelně naplánovány a propracovány, nesmí docházet k chybám na pracovišti. Kariérový postup je pomalý a zohledňuje se u něj preciznost konání. U rozvoje pracovníků je kladen důraz na rovnováhu mezi potřebou individuálního a podnikového rozvoje.

4. Kultura mašliček - Rozvoj a vzdělávání pracovníků je uskutečňováno v prrípadě, pokud si to daná pracovní pozice vyžaduje. Týká se to především pracovních pozic, kde je vyžadována pečlivost a přesnost.

Je zřejmé, že popsané typy kultur popisují především dopad podnikové kultury na rozvoj pracovníka.

„Pracovníci jsou chápáni jako aktivum, jako bohatství podniku nebo jako lidský kapitál, do něhož je třeba investovat tím, že se jim budou poskytovat př́ležitosti ke vzdělávání a rozvoji.“25 Rozvoj pracovníka si podnik žádá a nárokuje, poněvadž chce zastavit dosavadní zastarávání know-how, svých služeb či výrobků. Pracovníci rozvoj vítají, nebot' tak mohou uspokojit své sociální a psychologické potřeby, zejména jde o seberealizaci, růst na sociálním žebřičcku a zvýšení podílu na odpovědnosti. Podniky proto také poskytují svým pracovníkům „doplňkový“ rozvoj, jež si nevyžaduje daná pracovní pozice (např. jazykové kurzy).

Podnik se ovšem nezaměřuje pouze na rozvoj pracovníka, ale věnuje se také:

a) „personální práci - jedná se o zabezpečování optimálního počtu pracovníků v optimální sociálně demografické a profesně kvalifikační struktuře pracovníků, kteří budou optimálně rozmístěni a jejichž pracovní potenciál bude v každém okamžiku nejen efektivně využíván, ale současně bude neustále podporován jeho další rozvoj. Zde tím tedy rozumíme péči o lidi v podniku především jako o pracovníky.

b) sociální práci - zde jde především o vytváření a obnovu podmínek, bez nichž není možné splnění definovaných personálních cílů. Jedná se tedy o snahu umožnit pracovníkům naplno uplatňovat svi̊j znalostní, schopnostní a dovednostní potenciál. Tuto práci můžeme tedy chápat jako péči o pracovníky podniku především jako o lidi. Realizace sociální politiky by měla být adresná (určena konkrétním skupinám, a pokud je to možné, tak i konkrétním lidem), individuální a diferencovaná (odrážející

\footnotetext{
${ }^{24}$ MALÁTEK, V. Problematika utváření znalostní a dovednostní struktury manažera v podmínkách České republiky. 2008, s. 85.

${ }^{25}$ ARMSTRONG, M. Řízení lidských zdrojů. Nejnovější trendy a postupy. 2007, s. 31.
} 
vnitřní strukturu pracovníků), mnohotvárná a dynamická (měla by být přitažlivá a atraktivní a odpovídat potřebám zaměstnanců),

c) vedení lidí - vedení lidí má významný vliv na ochotu pracovníků určitou práci vykonat a tím i na kvalitu výstupu této práce. Způsob, jakým je vrcholové vedení zainteresováno na snaze rozvíjet znalosti a dovednosti pracovníků a jakým způsobem nadřízení eventuálně vedoucí týmů jednají s pracovníky, má v podstatě vždy vliv na jejich rozhodnutí. Rozhoduje-li se např́klad pracovník, zda poskytne své znalosti, bude jeho volba jiná $\mathrm{v}$ př́ípadě, že je mu dáván najevo souhlas a podpora, než $\mathrm{v}$ případě, že jsou jeho znalosti podceňovány nebo je vedení autokraticky zaměřeno. ${ }^{\text {‘26 }}$

„Podniková kultura, rozvíjení pracovníků a jejich vzdělávání se podílí na formování sociálního klimatu podniku. Za sociální klima podniku lze považovat vzájemné vztahy mezi pracovníky. Každá lidská činnost, má-li být společensky užitečná a prospěšná, předpokládá jistou pracovní pohodu. Práce vykonávaná v podmínkách nepř́iznivých pro pracovní výkon bývá obvykle málo kvalitní.“27 Je zřejmé, že dobré sociální vztahy mezi pracovníky jsou pro podnik velmi důležité a je zapotřebí, aby se podniky věnovali rozvoji nejen lidského kapitálu, ale také sociálního kapitálu.

„Podniky nabízejí svým pracovníků také další profesní vzdělávání. Toto vzdělávání se chápe jako součást jejich osobního rozvoje. Pod pojmem osobní rozvoj rozumíme soubor procesů, které pozitivně mění kvalifikaci, postoje, způsoby jednání apod. jednotlivých pracovníků. Ke zjištění potřeb rozvoje se používají obvykle tyto metody:“‘28

- písemné dotazníky,

- osobní rozhovory s pracovníky,

- hodnocení skutečné a potenciální výkonnosti pracovníků a vyvozování závěrů ze zjištěných rozdílů,

- testy a prověrky,

- pozorování pracovního jednání a chování zaměstnanců na pracovišti,

- podněcování zájmu zaměstnanců o vlastní osobní rozvoj a vytváření stimulujících podmínek pro tento záměr,

- skupinové diskuse,

- rozbory dokumentů (zejména personálních anamnéz),

- diskuse s pracovníky odpovědnými u podniku za vzdělávání,

- podněty a informace managementu apod.

J. Stýblo také uvádí, že by si pracovníci měli umět stanovit své silné a slabé stránky a na ty slabé stránky zaměřit další profesní vzdělávání. Je pak společným zájmem managementu, vedení podniku a pracovníků, aby společně hledali řešení a volili takové metody vzdělávání, které povedou ke zdokonalení a rozvoje pracovníka.

\section{Závěr}

„T. Kollárik uvádí, že člověk je př́rodně společenská bytost, jeho činnost a psychika, která ji řídí jaksi zevnitř, je determinována také sociálními činiteli, k nimž patří především sociální systém pracovního prostředí, v němž člověk tráví mnoho času a který se také proto, že se člověk v jeho rámci realizuje jako pracovník, tvůrce určitých hodnot, stává přirozenou

\footnotetext{
${ }^{26}$ BUREŠ, V. Řízení intelektuálního kapitálu. 2003, s. 77.

27 ŠMÍD, L. Mezilidské vztahy v životě a na pracovišti. 1985, s. 68.

${ }^{28}$ STÝBLO, J. Personální management. 1993, s. 217.
} 
složkou jeho životního prostř̌edí،“' ${ }^{29} \mathrm{Z}$ našeho článku a výše uvedeného jednoznačně vyplývá, že v každé lidské činnosti, a té pracovní nevyjímaje, jsou přítomny sociálně-psychologické aspekty, na něž je potřeba $v$ rámci motivace a rozvoje pracovníků pozitivně působit, na což se v praktickém ř́zení lidských zdrojů někdy pozapomíná. Jedině tak lze totiž dosahovat kladných výsledků nejen v těchto personálních činnostech, ale v plnění podnikových cílů obecně. Je důležité zdůraznit skutečnost, že pokud dochází k rozvoji pracovníků, v konečném důsledku dochází také k rozvoji podniku jako celku. Okolní podmínky se neustále mění, a proto je důležité se umět přizpůsobit. V současnosti podnik obstojí v konkurenci jedině prostřednictvím svých, vhodně motivovaných, pracovníků, kteři mají potřebné znalosti, dovednosti a schopnosti. Jsou to právě lidé, kteří zajistí rozvoj a přežití podniku. Lidé jsou základním stavebním kamenem podniku a vhodně zvolená podniková kultura, správné sociální klima, osobnostní růst, vhodné metody motivace a rozvoje pracovníků výrazně přispívají k podnikovému „růstu““.

\section{Literatura:}

[1] ARMSTRONG, M. Ǩizení lidských zdrojů. Nejnovější trendy a postupy. 10. vyd. Praha : Grada Publishing, 2007, 800 s. ISBN 978-80-247-1407-3.

[2] BUREŠ, V. Řizení intelektuálního kapitálu. Liberec : E+M Ekonomie a Management, 2003, roč. 6, č. 3, s. 77-82. ISSN 1212-3609.

[3] CEJTHAMR, V., DĚDINA, J. Management a organizační chování. Praha : Grada Publishing, 2005, 340 s. ISBN 80-247-1300-4.

[4] DVOŘÁKOVÁ, Z. a kol. Management lidských zdrojů. 1. vyd. Praha : C. H. Beck, 2007, 485 s. ISBN 978-80-7179-893-4.

[5] HRONÍK, F. Rozvoj a vzdělávání pracovnikỉ. 1 vyd. Praha : Grada Publishing, 2007, 240 s. ISBN 978-80-1457-8.

[6] Intelektuální kapitál [online], [cit. 2011-06-23]. Dostupné z: 〈http://managementmania.com/intelektualni-kapital>.

[7] KOCIÁNOVÁ, R. Personální činnosti a metody personální práce. 1. vyd. Praha : Grada Publishing, 2010, 224 s. ISBN 978-80-247-2497-3.

[8] KOUBEK, J. Řizení lidských zdrojio. 3. vyd. Praha : Management Press, 2003, 367 s. ISBN 80-7261-033-3.

[9] LIPŠOVÁ, V., ŠAMÁNEK, J., VAVŘINOVÁ, J. Kriteria kvality podpory zdraví na pracovišti [online], [cit. 2012-04-03]. Centrum pracovního lékařství, 2005. Dostupné z: 〈www.szu.cz/uploads/documents/cpl/.../kriteria-kvality-manual.doc〉.

[10]LOCKE, E. A., LATHAM, G. P. Goal setting : a motivational technique that works! 1. vyd. Prentice Hall, 1984, 193 s. ISBN 9780133574678.

[11]LUKÁŠSVÁ, R., NOVÝ, I. a kol. Organizační kultura. 1. vyd. Praha : Grada Publishing, 2004, 174 s. ISBN 978-80-247-0648-1.

[12] MALÁTEK, V. Problematika utváření znalostní a dovednostni struktury manažera v podmínkách České republiky. In Sociálně ekonomické a manažerské aspekty podnikatelské etiky. Bratislava : Eurounion, 2008, s. 58 - 98. ISBN 978-80-89374-00-7.

[13] MIKA, J. Etyka w edukacji dorostych-andragogice. In „Śląska Policja“ Kwartalnik Policji Garnizonu Śląskiego. Katowice : Warsztaty Szkolne, 2011, s. 13 - 16. ISSN 20825943.

[14]NAKONEČNÝ, M. Motivace pracovního jednání a její ř́zení. 1. vyd. Praha : Management Press, 1992, 258 s. ISBN 80-85603-01-2.

\footnotetext{
${ }^{29}$ NAKONEČNÝ, M. Motivace pracovního jednání a její ř́ízení. 1992, s. 37.
} 
[15] NAKONEČNÝ, M. Sociální psychologie organizace. 1. vyd. Praha : Grada Publishing, 2005, 228 s. ISBN 80-247-0577-X.

[16] PALÁN, Z. Lidské zdroje - Výkladový slovník. 1. vyd. Praha : Akademie věd České republiky, 2002, 280 s. ISBN 80-200-0950-7.

[17]PITUCHOVÁ, I. Lidský kapitál a jeho význam. In Sborník př́spěvků IV. Mezinárodní vědecké konference doktorandů a mladých vědeckých pracovníků. CD-ROM. Karviná : SU OPF, 2011. ISBN 978-80-7248-711-0.

[18] PAUKNEROVÁ, D. a kol. Psychologie pro ekonomy a manažery. 3. vyd. Praha : Grada Publishing, 2012, 259 s. ISBN 978-80-247-3809-3.

[19] STAEHLE, W. H. Management. Eine verhaltenwissenschaftliche Einführung. 2. vyd. Mnichov : Vahlen, 1985, 787 s. ISBN 978-3800611027.

[20] STÝBLO, J. Personální management. 1. vyd. Praha : Grada Publishing, 1993, 256 s. ISBN 80-85424-92-4.

[21] ŠERÁK, M. Zájmové vzdělávani dospělých. 1 vyd. Prahab: Portál, 2009, 208 s. ISBN 978-80-7367-551-6.

[22] ŠMÍD, L. Mezilidské vztahy v životě a na pracovišti. 1.vyd. Praha : Ústřední kulturní dům železničářů nositel Ceny Antonína Zápotockého, 1985, 106 s. ISBN 59-150-85-02-9.

[23] TURECKIOVÁ, M. Řizení a rozvoj lidí ve firmách. 1. vyd. Praha : Grada Publishing, 2004. 168 s. ISBN 80-247-0405-6.

[24] VETEŠKA, J., TURECKIOVÁ, M. Kompetence ve vzdělávání. 1. vyd. Praha : Grada Publishing, 2008, 159 s. ISBN 978-80-247-1770-8.

[25] VODÁK, J., KUCHARČÍKOVÁ, A. Efektivní vzdělávání zaměstnanců. 2. vyd. Praha : Grada Publishing, 2011, 240 s. ISBN 978-80-247-3651-8.

Klasifikace JEL: J24, J28, O15

\author{
Doc. RSDr. Vojtěch Malátek, CSc. \\ Docent - Katedra společenských věd \\ Obchodně podnikatelská fakulta v Karviné \\ Slezská univerzita v Opavě \\ Univerzitní náměstí 1934/3, 73340 Karviná \\ malatek@opf.slu.cz
}

